\title{
Regional Economic Development and Creative Class on the Example of the German State of North Rhine- Westphalia
}

\author{
Alexey Stepanov \\ Department of Economic Theory \\ Financial University under the Government of the Russian \\ Federation \\ Moscow, Russia \\ E-mail: AVStepanov@fa.ru
}

\author{
Irina Yurzinova \\ Department of Economic Theory \\ Financial University under the Government of the Russian \\ Federation \\ Moscow, Russia \\ E-mail: IYurzinova@fa.ru
}

\begin{abstract}
This article presents a brief analysis from the work of a researchers' group of the Institute of Regional and Structural Researchers at the Niederrhein University about the influence of the creative class on the development of the regional economy on the example of the German state North Rhine-Westphalia.
\end{abstract}

Keywords - social-economic development; regional economy; regional development; creative class; North Rhine-Westphalia

\section{INTRODUCTION}

The activities of people who can have a significant impact on the main factors' change and economic development conditions, has long been studied around the world as a significant factor of socio-economic development. It is quite relevant to analysis foreign scientists' experience from the perspective of its possible application to accelerate the socio-economic development of Russia.

From this point of view, the German state of North Rhine - Westphalia appears quite interesting. It belongs to the socalled "old industrial" regions, for which the search for new and non-standard factors of economic development is extremely important. The experience of economic development of this region, in our opinion, will be useful to the Russian regions belonging to the same group of "old industrial".

\section{THE CREATIVE CLASS IN THE CONCEPT OF RICHARD} FLORIDA

As one of the important factors of socio-economic development of the German region, the human factor was chosen, and the emphasis was made not on increasing the level of region population intellectual potential or on changing the structure of the labor force, but on the use of socio-economic potential of a special segment, called "creative class".

The creative class includes those segments of the employed able-bodied population that produce economic values in the process of creative activity rather than production. Thus, the determining factor in the success of economic activity and, as a consequence, the socio-economic development of the region, is the intellectual and creative potential, rather than the availability and efficient use of production capacity. It should be noted that this approach fully corresponds to the main modern concepts of economic relations development, which put the human factor, more precisely - intellectual potential, among the leading factors of economic development both separate regions and states as a whole.

Exploring the creative class influence on regional economic development, German scientists have taken as a basis the concept of Richard Florida, who identified three types of creativity that synergistically affect each other and, as a result, contribute to the economic development of the regions [5], [6], [7], [8]:

- Technology and innovation;

- entrepreneurial activity;

- $\quad$ art and culture.

Based on these three types, R. Florida divides the creative class itself into three subgroups in "Table I". 
TABLE I. The Structure of the Creative Class

\begin{tabular}{|l|l|l|}
\hline \multicolumn{1}{|c|}{ Segment } & \multicolumn{1}{|c|}{ Representatives } & \multicolumn{1}{c|}{ Role in economics } \\
\hline Super-creative core & $\begin{array}{l}\text { Engineers, doctors, teachers, scientists in } \\
\text { the field of natural, economic, social and } \\
\text { human sciences }\end{array}$ & $\begin{array}{l}\text { Generate knowledge, innovate and thus stimulate economic and } \\
\text { technological development }\end{array}$ \\
\hline Creative professionals & $\begin{array}{l}\text { Lawyers, managers, technicians, medical } \\
\text { personnel, etc. }\end{array}$ & $\begin{array}{l}\text { Support economic development by applying their knowledge in } \\
\text { new areas, especially in interaction with other people or } \\
\text { customers }\end{array}$ \\
\hline Art workers (bohemians) & $\begin{array}{l}\text { Musicians, writers, publicists, artists, } \\
\text { designers }\end{array}$ & $\begin{array}{l}\text { They represent a creatively active part of the creative class and do } \\
\text { not solve any economic problems, but the presence of this layer } \\
\text { serves an important indicator of the openness and attractiveness } \\
\text { of the region for the core and professionals }\end{array}$ \\
\hline
\end{tabular}

According to the research of German authors [10], representatives of innovative and creative professions in the state of North Rhine-Westphalia are unevenly distributed. In particular, the concentration of the creative class is the highest in agglomerations (cities), as well as in some adjacent districts, for example, in the Mettmann district, in the Rhine district of Neuss, as well as in RheinischBergische Kreis (district), where relatively high proportions of creative class representatives were revealed. It seems to us that this has an impact on the differences in the economic development rates of these areas, but the task of determining the strict interrelations between regional development and the creative class has not been fully solved to date.

\section{THE CREATIVE ClASS AND THE REgIONAL ECONOMIC DEVELOPMENT}

There are a number of analytical works [1], [3], [4], [9], [11], which explore the relationship between the creative class and its share of total employment, on the one hand, and regional economic development, on the other hand. A systematic analysis of all these works is needed in order to answer three main methodological questions:

- What statistical methods should be used in the analysis of the considered relationships; a. Source: compiled by the author based on the works [7], [ 8]

- which indicator in the given analysis will best reflect regional economic development;

- how the expected links between the creative class and regional development should be displayed.

A brief overview of the results obtained by German researchers [10] in an attempt to summarize the answers to these three questions will be given.

The literature analysis shows that in practice a wide range of statistical methods is used, such as correlation analysis, linear regression, multidimensional regression and spatial econometrics methods. Less often the analysis is performed on the basis of time series data. However, for the analysis of the situation in the North Rhine - Westphalia state it was possible to limit the use of relatively simple statistical methods: correlation analysis, linear regression and regression calculations performed on the basis of time series.

The next important task is to choose an indicator that can best describe regional economic development. Analysis of the literature shows that the following indicators are most often used in research in "Table II".

TABLE II. MAIN INDICATORS TO DESCRIBE REGIONAL ECONOMIC DEVELOPMENT

\begin{tabular}{|l|l|}
\hline \multicolumn{1}{|c|}{ Indicator } & \multicolumn{1}{c|}{ Purpose } \\
\hline $\begin{array}{l}\text { Gross regional product } \\
\text { (GRP) per capita }\end{array}$ & $\begin{array}{l}\text { It is most often used to measure well-being. It is used in the comparative analysis of regional economic } \\
\text { development, since calculations based on per capita indicators allow comparing regions (regional economies) } \\
\text { with different absolute values. }\end{array}$ \\
\hline $\begin{array}{l}\text { Gross regional product } \\
\text { (GRP) per employee }\end{array}$ & $\begin{array}{l}\text { It is determined by GRP not in relation to the total population, but in relation to those who actually produce it. } \\
\text { Thus, this value is not affected by regular labour migration of the population and allows to draw conclusions } \\
\text { about the economic impact of the population actually working in the region and, accordingly, about labour } \\
\text { productivity. }\end{array}$ \\
\hline $\begin{array}{l}\text { Change rate in gross } \\
\text { regional product }\end{array}$ & \begin{tabular}{l} 
It is used to estimate the change in regional macroeconomic indicators over time. \\
\hline Employment growth
\end{tabular} \\
$\begin{array}{l}\text { It is used to assess the labour market development over time. The empirical analysis does not take into account } \\
\text { the level of employment, since the level of the economically active population depends on the region } \\
\text { population and is therefore not suitable for interregional comparisons. }\end{array}$ \\
\hline
\end{tabular}

Source: compiled by the author based on the materials [10]

In addition to the indicators of "Table II" in some works other indicators can also be used. For example, business startups are used as one of the economic activity indicators in [2].

As the main limitation of the indicator use based on GRP, it can be possibly pointed to the inevitable loss of accuracy associated with the lack of accounting in the calculation of GRP:

- Non-market services (legal - in private households, illegal — in the shadow economy);

- Important external factors (environmental damage, etc.); 
- Loss of economic assets due to natural disasters.

However, despite this, GRP in most cases remains the only available value that provides comprehensive information on the effectiveness of the regional economy.

It should be noted that currently the GRP indicator (or its analogue - gross domestic product, GDP) is not the only aggregated indicator characterizing economic and socioeconomic development. For example, in China, a more important development indicator is the GDP structure balance, and in the Kingdom of Bhutan, "gross national happiness" is generally used as an indicator of economic development. The shift of emphasis from quantitative to qualitative indicators seems to us quite reasonable, as it more fully corresponds to the current trends in the increasing role of intellectual potential in economic development.

Finally, the last methodological task is to choose an adequate way to reflect the creative class influence on regional economic development. In [10], the solution of this problem is given priority, and German researchers formulate this problem as follows: it is necessary to determine what specific relationship should be subjected to empirical analysis. The problem in this case can be identified as follows: a systematic analysis of empirical literature sometimes gives the impression that all known approaches have been tested, but ultimately only those that provided statistically reliable results have been used. Rarely is the justification of the evaluation approach based on any predefined and described theoretical model (from the sources we used the exception is the work [4]).

\section{THE MAIN HYPOTHESES OF GERMAN RESEARCHERS}

The main hypotheses most frequently encountered in empirical analysis and the critical evaluation of these hypotheses given by German researchers in [10] are listed below. In general, we agree with the critical remarks of our German colleagues and believe that their full consideration is likely to improve the reliability of the results that will be obtained in future studies:

Thesis 1 . GRP growth rate is a non-decreasing function of the share of creative class representatives in the total number of employed.

The main hypothesis is that the higher the share of the creative class in the total number of employees is, the higher the growth of the gross regional product will be. Since the share of the creative class does not have a direct impact on economic growth, it will in any case manifest itself indirectly: if the share of creative people increases, the average productivity increases. There are two possible explanations for this theoretical relationship:

- If the productivity of the creative class representative is higher than that of an ordinary employee, the shift in the composition of the employed population leads to an increasing average productivity of workers (arithmetic effect).

- The creative class and its ideas force ordinary workers to work with higher own productivity, which also increases the average productivity of all workers (creative effect)

German researchers believe that if average productivity increases as described above, gross regional product will grow faster than without this effect (confirmation of the hypothesis). However, it should be taken into consideration that with an increase in the creative class share, economic growth may actually decrease due to a total population employment decrease. Therefore, theoretically, the result deviating from the hypothesis can also be quite plausible.

Thesis 2. Employment growth is a non-decreasing function of the creative class share in total employment.

The main hypothesis is that the higher the share of the creative class in total employment is, the higher the employment growth will be. Here, too, it is difficult to justify the direct influence of the creative class share on the change in the number of employees; again, indirect correlations may be more relevant to substantiate the hypothesis. It is obvious that a significant part of the creative class (as a kind of catalyst) will contribute to the creation of additional jobs, which, however, will have the opposite deterrent effect on this group. Of course, with this approach, it is important to note that the creative class share cannot be the only determining factor in the development of regional employment - regional structural and local conditions, as well as the overall economic situation, are also significant. The factors mentioned can lead to a decrease in employment as a whole with an increase in the creative class share. Therefore, a result that deviates from the hypothesis cannot be excluded here either, for theoretical reasons.

Thesis 3. The economic return of the economically active (employed) population, defined as the GRP per employed person, is a function of the creative class share in the total number of employed. At the same time, the growth rate of economic returns is always higher than the growth rate of the creative class share in the total number of employees

The main hypothesis is that the higher the share of the creative class in total employment is, the higher the average labour productivity appears to be. The direct influence of the creative class share on productivity can theoretically be justified on the basis of the neoclassical Cobb-Douglas production function with two "types" of the production factor $\mathrm{L}$ - creative and non-creative; in this case, it can be shown that productivity depends solely on the creative people share in total employment and capital intensity (a similar approach is described in [4]). As indicated in [10], the direct effect is the result of two effects that are difficult to separate empirically:

- At a higher average productivity of creative class representatives, the shift in the composition of employment towards the creative class leads to an increase in the average productivity of all employed workers (arithmetic effect);

- Representatives of the creative class can increase the productivity of other production factors used as 
impulse generators, which also increases the average productivity of all employees (creative effect).

According to our opinion, this hypothesis needs further test.

Thesis 4. The value of GRP per capita is a function of the creative class share in total employment. At the same time, the growth rate of this indicator is always higher than the growth rate of the share of representatives of the creative class in the total number of employees.

The main hypothesis is that the higher the share of creative people in total employment is, the higher the average per capita income is likely to be. This result can be theoretically justified, but in essence it is based on numerical arithmetic [10]:

- If the representatives of the creative class due to their obviously higher qualification, achieve a higher average performance than the ordinary employed, the shift in the composition employed in the direction of the representatives of the creative class also leads to a general increase in income per capita;

- The effect can be enhanced if representatives of the creative class will help to increase the productivity of ordinary employees and equalize their wages in relation to productivity.

The arguments described above were provided with respect to the results obtained by various researchers using the methods of correlation analysis and linear regressions. These arguments cannot be fully transferred to the results obtained from the time series analysis, since the method is mainly based on the hypothesis that the development of employment in the creative class has a positive impact on regional employment over time. However, this hypothesis now also needs to be confirmed.

\section{CONCLUSION}

In conclusion, it can be noted that the study of the creative class as a segment of the economically active population that can become a factor in the economic development of the region is very promising and relevant for Russia. However, the currently used methodological and methodical apparatus of such studies has not yet been fully developed. In addition to methodological and methodical developments, an important task is also to comprehend and systematically summarize the foreign experience in the application of this methodology in the management of regional economic development.

\section{REFERENCES}

[1] Andersen, K.V.; Lorenzen, M. The Geography of the Danish Creative Class, - A Mapping Analysis. Kopenhagen, 2005

[2] Audretsch, D.; Dohse, D. und Niebuhr, A. Cultural diversity and entrepreneurship: A regional analysis for Germany. In: Annals of Regional Science, Vol. 45, Jg. 2010, S. 45-85.

[3] Clifton, N.; Cooke, Ph. The Creative Class in the UK. Regional Industrial Research Report 46. Cardiff, 2007
[4] Falck, O.; Fritsch, M.; Heblich, S. Bohemiens and Regional Economic Growth, Jena Economic Research Papers, Vol. 049, Jg. 2009, Jena 2009

[5] Florida, R. The rise of the Creative Class - And how its transforming work; S 21ff; Leisure, Community and everyday Life; New York, 2002

[6] Florida, R. Why cities without gays and rock bands are losing the economic development race, In: Washington Monthly; May 2002

[7] Florida, R. Cities and the Creative Class; New York: Routledge, 2005.

[8] Florida, R.; Tinagli, I. Technology, talent and tolerance - Europe in the creative age; German translation in: Perspektive21, Vol. 31 July 2006.

[9] Fritsch, M.; Boschma, R. The Geography and the Effect of Creative People in Germany. Jena Economic Research Papers, Vol. 001, Jg. 2007, Jena 2007

[10] Gottschalk, Ch., Hamm, R., Imöhl,I. The Importance of the Creative Class for the Economic Development of North Rhine-Westphalian Regions (Final Report) [Electronic resource]. Access mode: www.creative.nrw.de. (Accessed: 17.02.2018).

[11] Quian, H. Talent, Creativity and Regional Performance: The Case of China. In: Annals of Regional Science, 2010, Vol. 45, S. 133-156. 